УДК 35.07(455)

H. С. Орлова,

д. держ. упр., професор, професоркафедри державного управління,

публічного адміністрування та регіональної економіки,

Харківський начіональний економічний університет імені Семена Кузнеия

ORCID ID: 0000-0003-0785-751X

Ю. А. Мохова,

д. держ. упр., дочент магістратури державного управління Центру післядипломноі

освіти, Аонещький начіональний технічний університет, м. Покровськ

ORCID ID: 0000-0002-0093-2620

DOI: $10.32702 / 2306-6814.2022 .1 .61$

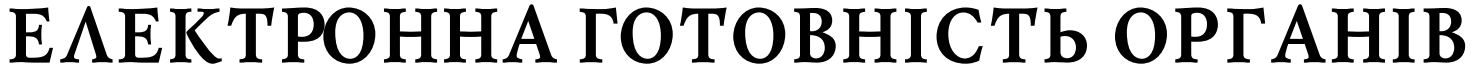

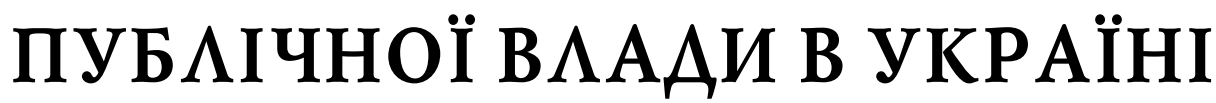

\author{
N. Orlova, \\ Doctor of Science in Public Administration, Professor, Professor of the Department of Public Administration, Public \\ Administration and Regional Economy, Semyon Kuznets Kharkiv National University of Economics \\ Y. Mokhova, \\ Doctor of Science in Public Administration, Associate Professor of Master of Public Administration of the Center for \\ Postgraduate Education, Donetsk National Technical University, Pokrovsk
}

\section{ELECTRONIC READYNESS OF PUBLIC AUTHORITIES IN UKRAINE}

УВ статті обгрунтовано, що, попри наявність достатніх передумов для переходу до методів електронного управління актуальною залишається проблема покращення рівня електронної готовності в органах публічної влади. Метою статті є визначення ефективних напрямів підвищення рівня електронної готовності органів публічної влади для успішного реформування системи публічного управління в Україні. Інформаційною базою дослідження є статистичні дані Міністерства цифрової трансформації України, офіційні вебсайти Пенсійного фонду України, Державної податкової служби, Національної служби здоров'я України, Національного агентства України з питань державної служби, Міністерства внутрішніх справ, статистичні дані та звіти про результати їх діяльності. На основі дослідженення досягнень усфері електронного урядування та з метою визначення ефективності реалізації концепції електронного урядування проведено оцінку електронної готовності органів державного управління на основі аналізу показників кількості зареєстрованих користувачів, наданих електронних послуг, опрацьованих електронних звернень. Запропоновано заходи для підвищення електронної готовності на рівні державної установи, реалізація яких дозволить підвищити ділову репутацію установи та конкурентоспроможність електронних послуг, що надаються органом.

The article substantiates that despite the existence of sufficient prerequisites for the transition to e-government methods, the problem of improving the level of e-readiness in public authorities remains relevant. The aim of the article is to identify effective ways to increase the level of e-readiness of public authorities for the successful reform of the public administration system in Ukraine. The information base of the study is the statistics of the Ministry of Digital Transformation of Ukraine, the official websites of the Pension Fund of Ukraine, the State Tax Service, the National Health Service of Ukraine, the National Civil Service Agency of Ukraine, the Ministry of Internal Affairs, statistics and reports. Based on the study of achievements in the field of e-government and to determine the effectiveness of the concept of e-government, an assessment of e-readiness of public administration was conducted based on analysis of the number of registered users, provided e-services, processed 
e-applications. The results of the assessment of electronic readiness of the Pension Fund of Ukraine, the State Tax Service, the National Health Service of Ukraine, the National Agency of Ukraine for Civil Service, the Ministry of Internal Affairs allowed to allocate the State Tax Service, National Health Service of Ukraine, National Agency of Ukraine for Civil Service, as public administration bodies with a high rate of electronic readiness, which indicates the adoption of highly effective management decisions and the implementation of an effective management system at the level of public administration. Measures are proposed to increase e-readiness at the level of public institutions (ensuring sustainable and secure operation of e-services; providing reasoned responses to citizens 'proposals, their fuller consideration and accountability of officials, including online deshboards and online trackers of citizens' inquiries and answers authorities working in real time to increase accountability, strengthening the analytical capabilities of public open data monitoring tools with artificial intelligence algorithms to detect non-obvious corruption risks), which will increase the business reputation of the institution and the competitiveness of electronic services provided by the body.

КлючоВі слоВа: електронне урядуВання, електронна готовність, публічна Влада, інформачійно-телекомунікаційнісистеми, інфрормація.

Key words: e-government, e-readiness, public authority, information and telecommunication systems, information.

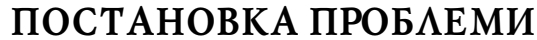

Електронна готовність розуміється як багатомірне соціально-технологічне явище, яке складається із певних сорер діяльності, які включають у себе такі сорери готовності: доступна інфрраструктура, ефективне управління, демократичне управління та корисні послуги. В органах публічної влади є достатні передумови для переходу до методів електронного управління та покращення рівня електронної готовності. Найбільшими пріоритетами $є$ залучення населення до методів електронного урядування, стимулювання електронної демократії, які в свою чергу вимагають запровадження надання адміністративних електронних послуг населенню та бізнесу. Актуальним залишається проблема інформаційно-комунікаційного забезпечення процесу та підготовка державних службовців та користувачів до впровадження цифрових технологій.

\section{АНА $\Lambda$ IЗ ОСТ АHНIX АОС $А$ АЖЕНЬ І ПУБАІКАЦІЙ}

Питання розбудови інформаційного суспільства та використання потенціалу новітніх інформаційних технологій в публічному управлінні дослідили Амосов О. [1], Бурик 3. [2], Гордіенко Л. [1], Клімушин П. [3], Клименко І. [4; 5], Линьов К. [4], Литвинова Г. [5], Мохова Ю. [6; 7], Орлова Н. [2, 6; 7], Панчук А. [5], Ралдугін Є. [5] Спасібов Д. [8], Фурашев В. [9], Ющенко Н. [1] та інші. Низький ступінь електронної готовності органів публічної влади свідчить про наявність проблем, які потребують терміного вирішення. Попри достатню кількість наукових праць у цьому напрямі необхідним $€$ виділення напрямів підвищення рівня електронної готовності органів публічної влади для розвитку електронного урядування та інформаційного суспільства.

\section{METOЮ СТАTTI}

Метою статті $\epsilon$ визначення ефективних напрямів підвищення рівня електронної готовності органів публічної влади для успішного реформування системи публічного управління в Україні.

\section{ВИК ААА ОСНОВНОГО MATEPIA $\Lambda$ У}

Методики оцінки електронної готовності, прозорості, е-демократії направлені на виявлення стану, у якому знаходиться електронне урядування в Україні та на формування засад для постійно діючого регулярного моніторингу, сумісного із підходами, прийнятими у $\in C$.

Оцінка електронної готовності розуміється як багатомірне соціально-технологічне явище, яке включає організаційно-технічну базу, сферу електронного управління, фрактори ефективності електронного управління. Кожна із складових має базові індикатори оцінки сегменту.

На виконання доручення Кабінету Міністрів України Національним центром електронного урядування ДП "Держінформресурс" в анонімному порядку проведено опитування профрільних слухачів Національної академії державного управління при Президентові України з метою оцінки готовності використовувати інформаційні технології в управлінні на благо людей та підвищення ефрективності управління. Результати опитування свідчать про те, що працівники обласних державних адміністрацій (ОДА) мають нижчий рівень електронної готовності, ніж працівники центральних органів виконавчої влади (ЦОВВ) через різний статус установ і завдань, які вони вирішують. Графрічно індекси електронної готовності представлено на рисунку 1. 


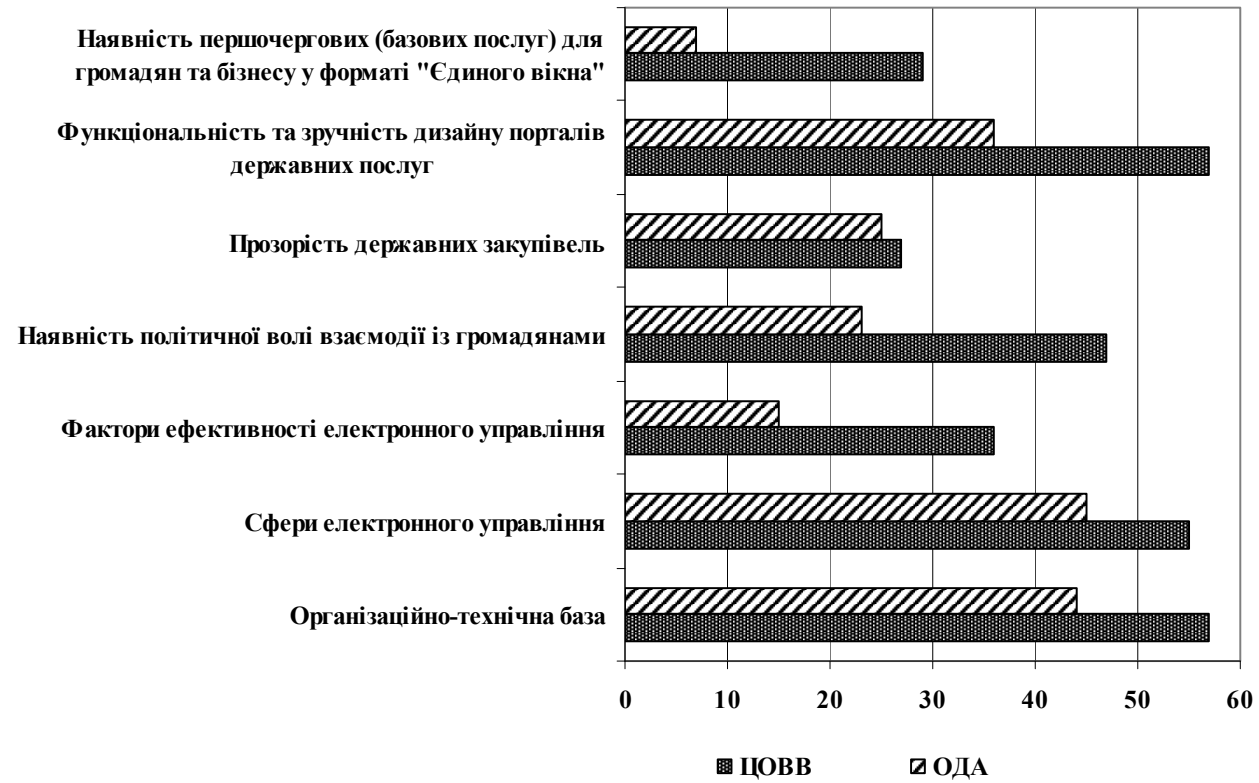

Джерело: [10].

Рис. 1. Індекси електронної готовності

Враховуючи сучасні тенденції розвитку електронного урядування проведемо дослідження електронної готовності органів публічної влади на прикладі лідерів з цифровізації державних послуг: Пенсійний фонд України, Державна податкова служба, Національна служба здоров'я України, Національне агентство України з питань державної служби, Міністерство внутрішніх справ.

В якості джерел інформації використані доступні статистичні дані та звіти про результати діяльності органів публічної влади, офіційні вебсайти, системи електронного документообігу та інорормація центрів надання адміністративних послуг.

Стратегія модернізації та розвитку Пенсійного фонду України на період до 2020 року, схвалена розпорядженням Кабінету Міністрів України від 14 вересня 2016 р. №672-р, включає такі напрями: впровадження електронної системи керування прийомом громадян 3 урахуванням контролю часу та якості обслуговування, оцифрування електронних пенсійних справ, розширення спектру електронних послуг.

Головним електронним сервісом Пенсійного фронду України, який допомагає громадянам отримати електронні послуги дистанційно, є вебпортал електронних послуг Пенсійного фонду України. На вебпорталі електронних послуг страхувальник, пенсіонер, роботодавець може вирішити питання пенсійного страхування, не звертаючись особисто до працівників Пенсійного фронду України. Станом на 01.01.2021 року на вебпорталі Фонду зареєстровано 4,8 млн користувачів, з них 1,2 млн за допомогою кваліфікованого електронного підпису. Здійснено 137,4 тис. записів на прийом, подано 48,7 тис. заяв на призначення пенсії та 22,6 тис. - на перерахунок пенсії, опрацьовано 160,4 тис. електронних звернень, сфрормовано понад 2,9 млн довідок з QR-кодом [11].

Державна податкова служба України (ДПС) одна з перших у країні розпочала розвивати електронні послуги та сервіси та нині надає якісні та зручні послуги платни- кам, ефрективно адмініструє податки, збори та платежі і виявляє нетерпимість до корупції.

Сервіси податкової доступні фрізичним особам на двох платорормах - в електронному кабінеті та на порталі Дія в розділі "Мої податки". Через особистий кабінет на порталі фрізичні та юридичні особи можуть надавати податкову звітність, листуватися з податковими органами, отримувати актуальну інформацію про стан розрахунків з бюджетом тощо. На порталі $€$ можливість ознайомитися з електронною пенсійною справою, отримати дані з Реєстру застрахованих осіб, звернутися до органів Пенсійного фронду України тощо. Замовникам пропонуються окремі е-послуги з реєстрації бізнесу та громадських організацій, отримання документів 3 державних реєстрів Міністерства юстиції України. Через кабінет доступними $\epsilon$ електронні сервіси Головного сервісного центру Міністерства внутрішніх справ України, зокрема щодо індивідуальних номерних знаків, уточнення даних у реєстрі посвідчень водіїв, уточнення даних у реєстрі свідоцтв про реєстрацію транспортного засобу, відновлення та обміну посвідчення водія. ДПС продовжує реалізувати проєкти цифрової трансфрормації в системі оподаткування, за допомогою яких адмініструвати та сплачувати податки максимально зручно і просто [12].

До переліку інформаційно-телекомунікаційних систем (ITC), що функціонують у ДПС, відносять: ITC "Податковий блок", ITC "Управління документами", ITC "Офріційний вебпортал", ITC "Єдине вікно подання електронної звітності", ІТС "Електронний кабінет", ІТС "Фінанси і персонал", ITC "Державний реєстр фрізичних осіб-платників податків". В ІТС зареєстровано 21,6 тис. актуальних користувачів органів ДПС, активовано 985 тис. ролей. Сервісами для громадян скористались 432 тис. осіб.

Міністерством цифррової трансфрормації спільно 3 Державною податковою службою за 2 роки створено та успішно реалізуються низка революційних проєктів. Результатом спільної роботи стало створення нових 
можливостей для платників податків. Лише за 3 місяці з моменту запровадження 7 найбільш запитуваних послуг податкової на порталі Дія, який забезпечує прозорість, простоту, зручність надання державних послуг громадянам та бізнесу онлайн, ДПС опрацьовано понад 20 млн запитів, щодня опрацьовується 220 тис. запитів. У рамках роботи з електронним документообігом в органах ДПС створено 309,3 млн електронних документів, більше 1,3 млн електронних документів обробляються за добу [12].

Національна служба здоров'я України (НСЗУ) є центральним органом виконавчої влади, який реалізує державну політику у сорері державних фрінансових гарантій медичного обслуговування населення. НСЗУ активно впроваджує електронні інструменти на кожному етапі трансорормації системи.

Трансформація системи охорони здоров'я відбувається паралельно з цифровою трансформацією. Відкрита статистика ведення електронних медичних записів дозволяє власникам та керівникам закладів охорони здоров'я бачити реальну картину щодо попиту на відповідних лікарів та обстеження. У 2021 році заплановано старт низки сервісів та функціоналу: електронний лікарняний (сервіс дозволить позбутися паперової роботи з оформлення листка непрацездатності як для пацієнта, так і для лікаря з роботодавцем); план лікування (модуль допоможе лікареві зробити всі необхідні призначення та полегшить контроль їх виконання); електронний кабінет пацієнта (сервіс дозволить пацієнту бачити власну електронну медичну картку, подавати декларації онлайн, мати доступ до власних даних); модуль чутливих даних, який забезпечить ведення електронних медичних записів з таких особливо чутливих нозологій, як ВІЛ-інфекція / СНІД та розлади психіки [13].

Починаючи з 2004 року Національне агентство України з питань державної служби (НАДС) впроваджує інфрормаційні технології у відомчий документообіг, ставши першопрохідником у цій роботі, оскільки на той час в Україні не існувало не лише позитивного досвіду. Запровадження Інформаційної системи управління людськими ресурсами на державній службі (HRMIS) здійснюється в рамках виконання розпоряджень Кабінету Міністрів України від 24.06.2016 р. № 474-р "Деякі питання ресормування державного управління України" та від 01.12.2017 р. № 844-р "Про схвалення Концепції впровадження інфрормаційної системи управління людськими ресурсами в державних органах та затвердження плану заходів щодо її реалізації", Грантової угоди, укладеної між Україною, Світовим банком та Європейським Союзом.

Процес впровадження HRMIS передбачає поступове впровадження державними органами підсистем "Штат і персонал" та "Зарплата і табель", які дозволяють кожному працівнику цих державних органів використовувати підсистему "Особистий кабінет". У 2020 році 25 державних органів стали користувачами HRMIS. До HRMIS внесено інфрормацію щодо 16406 працівників [14].

Таблиця 1. Аналіз показників розвитку електронного урядування в органах державного управління в 2020 році

\begin{tabular}{|c|c|c|c|}
\hline $\begin{array}{c}\text { Орган } \\
\text { державного } \\
\text { управління }\end{array}$ & $\begin{array}{c}\text { Кількість } \\
\text { зареєстрованих } \\
\text { користувачів } \\
\text { інформаційного } \\
\text { порталу (платформи) } \\
\text { органу державного } \\
\text { управління, млн осіб }\end{array}$ & $\begin{array}{c}\text { Кількість } \\
\text { наданих } \\
\text { електронних } \\
\text { послуг, млн }\end{array}$ & $\begin{array}{c}\text { Кількість } \\
\text { зареєстрованих } \\
\text { електронних } \\
\text { звернень, тис. }\end{array}$ \\
\hline ПФУ & 4,8 & 3,3 & 100,5 \\
\hline ДПС & 21,6 & 263,3 & 601,4 \\
\hline HC3y & 14 & 119 & 305,6 \\
\hline НАДС & 38,03 & 27,8 & 400 \\
\hline $\mathrm{MBC}$ & 4,5 & 11 & 13,4 \\
\hline
\end{tabular}

Джерело: на основі [11-16].

Сьогодні Міністерство внутрішніх справ (MBC) забезпечує формування пріоритетних напрямів інфрорматизації апарату Міністерства та його територіальних органів із надання сервісних послуг МВС, Національної поліції України, Адміністрації Держприкордонслужби України, Національної гвардії України, Державної міграційної служби України, Державної служби України з надзвичайних ситуацій, закладів установ і підприємств, що належать до сорери управління МBC [15].

Відповідно до Стратегії розвитку органів системи МВС України на період до 2020 року та Концепції розвитку електронного урядування в Україні Урядом затверджено Положення про єдину інформаційну систему Міністерства внутрішніх справ та переліку її пріоритетних інформаційних ресурсів (постанова Кабінету Міністрів України від 14 листопада 2018 року № 1024 ). Сервісні центри МВС налічують 4,5 млн користувачів. За 2020 рік за допомогою онлайн-сервісів видано більше 4,4 млн довідок про несудимість, проведено 2 млн реєстраційних операцій, видано 313,3 тис. посвдчень водія вперше, проведено 558,7 тис. відновлень (обмінів) посвідчень водія, здійснено 1760 замовлень індивідуальних номерних знаків [15].

Протягом 2019 року органами МВС супроводжувалось 11,3 тис. кримінальних проваджень щодо порушення кібербезпеки, виявлено 6 тис. правопорушень у сорер використання інформаційних технологій, викрито 11 організаційних груп, 8 транснаціональних хакерських угрупувань. Структуру кримінальних правоворушень в галузі інформаційної безпеки наведено на рисунку 2. 


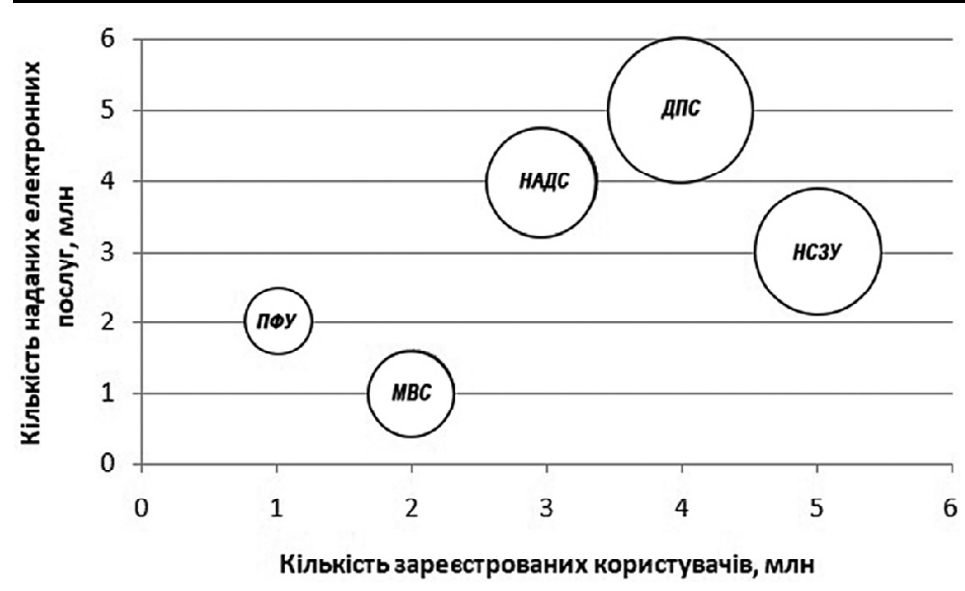

Рис. 3. Діаграма розміщення органів державного управління за рангами згідно з обраними показниками

Джерело: сформовано авторами.

Найбільша частка правоворушень пов' язана з втручанням в роботу Інтернет-ресурсів (45\%) та створенням та бутом шкідливих програмних засобів (27\%).

Для оцінки електронної готовності суб'єктів державного управління обрано проаналізувати такі показники діяльності органів державної влади: кількість зареєстрованих користувачів інформаційних порталів, кількість наданих електронних послуг, кількість електронних звернень.

Аналіз показників розвитку електронного урядування за визначеними органами державної влади представлено в таблиці 1

Виходячи із показників кількості зареєстрованихкористувачів, наданих електронних послуг, опрацьованих електронних звернень, зробимо ранжировку органів публічної влади. Для цього використаймо вбудовану функцію РАНГ (1) у MS Excel:

РАНГ $\left(a_{i} ;\right.$ масив; $\left.\mathrm{k}\right)$

де $\mathrm{a}_{\mathrm{i}}$ - рейтинг, для якого визначається ранг;

масив - посилання на дані, які ранжуються (в цьому випадку - показники цифрровізації органів влади);

$\mathrm{k}$ - число, яке визначає спосіб упорядкування (якщо k=0, то ранг визначається для списку, відсортованого в порядку убування, інакше - у порядку зростання).

Розглянемо діаграму розміщення органів державного управління згідно з отриманими ними рангами за наведеними показниками, в якій ось х включає ранг державного органу за кількістю зареєстрованих користувачів на інформаційних ресурсах, ось у - ранг державного органу за кількістю наданих електронних послуг, ранг за кількістю опрацьованих електронних звернень параметр, який визначає розмір об'єкту (органу) на карті (рис. 3).

Найвищий рівень електронної готовності притаманний для органу державного управління з найбільшими значеннями показників зареєстрованих користувачів, наданих електронних послуг, опрацьованих електронних звернень, тобто на координатній площині рангів це точка $(5 ; 5 ; 5)$.

3 діаграми розміщення органів державного управління (рис. 3.) можна зробити висновок, що найближчими до координати $(5 ; 5 ; 5)$ (тобто орган влади, що отримав найбільший показник) в 2020 році $є$ ДПС $(4 ; 5 ; 5)$,
НСЗУ (5;3;4), НАДС (5;3;4). Найнижчі ранги за обраними показниками отримали МBC $(1 ; 2 ; 1)$ та ПФУ $(2 ; 1 ; 2)$, що свідчить про наявність проблемних питань в реалізації цифрової стратегії та необхідність її вдосконалення.

Таким чином, високий показник електронної готовності органів державного управління $€$ результатом прийняття високоефективних управлінських рішень та вдалої системи управління на рівні державного органу.

\section{ВИСНОВКИ}

Для підвищення електронної готовності органів державного управління необхідним є: забезпечення сталого та безпечного функціонування е-послуг; надання аргументованих відповідей на пропозиції громадян, більш повне їх врахування та відповідальність посадових осіб, зокрема у вигляді онлайн-дешбордів і онлайн-трекерів запитів громадян та відповідей влади, які працюють у режимі реального часу з метою збільшення підзвітності; посилення аналітичних можливостей інструментів громадського моніторингу великих відкритих даних алгоритмами на основі штучного інтелекту для виявлення неочевидних корупційних ризиків.

Зазначені напрями дозволять вітчизняним органам державного управління підвищити ділову репутацію установи, конкурентоспроможність електронних послуг, що надаються органом, та, як наслідок, бути лідером у реалізації концепції електронного урядування.

\section{Література:}

1. Амосов О.Ю., Гордіенко Л.Ю., Ющенко Н.В. Сучасні рейтингові оцінки розвитку електронного урядування та інформаційного суспільства. Теорія та історія державного управління. 2020. № 60. С.13-27.

2. Орлова Н.С., Бурик 3.М. Державна інформаційна політика в Україні в сорері охорони здоров'я. Експерт: парадигми юридичних наук і державного управління. 2021. № 2. С. 233-242.

3. Клімушин П. С. Стратегї та механізми електронного урядування в інформаційному суспільстві: монографрія. Харків: Вид-во ХарРІНАДҮ "Магістр", 2016. 524 с.

4. Клименко І.В., Линьов К.О. Технології електронного врядування. Київ: Центр сприяння інституційному розвитку державної служби, 2006. 192 с.

5. Клименко І.В., Панчук А.М., Ралдугін Є.О., Литвинова Г.С. Моделювання, інфрормаційні системи і технології в державному управлінні: навчальний посібник. Київ: Центр навчальної літератури, 2004. 263 с.

6. Мохова Ю., Орлова Н. Роль цифррових компетентностей у формуванні ціфрового суспільства. Наукові перспективи. 2021. № 5 (11). С. 154-162.

7. Орлова Н., МоховаЮ. Європейські орієнтири цифрових трансорормацій у електронному урядуванні. Наукові перспективи. 2021. №7 (13). С. 97-106.

8. Спасібов Д. Електронне урядування в системі сучасних концепцій публічного управління. Теорія та практика державного управління. 2018. № 2 (61). URL: http:/ /www.kbuapa.kharkov.ua/e-book/tpdu/2018-2/ index.html (дата звернення 20.12.2021). 
9. Фурашев В. Електронне інформаційне суспільство України: погляд у сьогодення і майбутнє. Київ: Інжиніринг, 2005. 215 с.

10. Оцінка електронної готовності України. URL: https://www.nas.gov.ua/siaz/Ways_of_development_of_Ukrainian_science/article/14026.1.007.pdf (дата звернення 20.12.2021).

11. Звіт за 2020 рік. Пенсійний фонд України. URL: https://docs.google.com/viewer?url=https:// www.pfu.gov.ua/content/uploads/2021/03/Zvit_pro_robotu_ta_vykonannya_byudzhetu_PFU_2020.pdf (дата звернення 20.12.2021).

12. ДПС наданопонад 15 млн сервісних послуг на порталі рік. Дія. Державна податкова служба. URL: https://cabinet.tax.gov.ua/news/C9F9362A$183 \mathrm{~F} 0014 \mathrm{E} 0530 \mathrm{~A} 5028077926$ (дата звернення 20.12.2021).

13. Звіт Національної служби охорони здоров'я за 2020 рік. Національна служба охорони здоров' я. URL: file:///D:/\%D0\%B4\%D0\%B8\%D1\%81\%D0\%B5\%D $1 \% 80 \%$ D $1 \% 82 \%$ D0 \% B0 \% D $1 \% 86 \%$ D0 \% B $\%$ D1\%8F /\%D0\%B4\%D0\%BE\%D0\%BA\%D1\%82\%D0\%BE\%D1\%80\%D1\%81\%D0\%BA\%D0\%B0\%D1\%8F/ nhsu-annual-report-2020-ua-web.pdf (дата звернення 20.12.2021).

14. Аналітичний звіт про індивідуальні потреби у професійному навчанні державних службовців на 2021 рік. Київ: Національне агентство України з питань державної служби, 2021. 37 с.

15.Півстоліття інфрорматизації: розвиток інформаційної служби МВС таїї найбільші проєкти цифровізації. Портал Міністерства внутрішніх справ. URL: https:// mvs.gov.ua/uk/press-center/news/pivstolit tyainformatizaciyi-rozvitok-informaciinoyi-sluzbi-mvs-tayiyi-naibilsi-projekti-cifrovizaciyi (дата звернення 28.04.2021).

16. Кіберполіція. Портал Міністерства внутрішніх справ. URL: https://mvs.gov.ua/uk/press-center/ infographics/kiberpoliciya-2018 (дата звернення 28.04.2021).

\section{References:}

1. Amosov, O. Yu. Hordienko, L. Yu. and Yuschenko, N. V. (2020), "Modern rating assessments of the development of e-government and information society", Teoriia ta istoriia derzhavnoho upravlinnia, vol. 60, pp. $13-27$.

2. Orlova, N.S. and Buryk, Z.M. (2021), "State information policy in Ukraine in the field of health care", Expert: paradigms of legal sciences and public administration, vol. 2, pp. 233-242.

3. Klimyshyn, P. C. (2016), Ctratehii ta mexanizmy elektponnoho ypiadyvannia $v$ infopmatsijnomy cycpil'ctvi [Strategies and mechanisms of electronic management in the information community], KhARI NADU "Mahistr", Kharkiv, Ukraine.

4. Klymenko, I.V. and Lyn'ov, K.O. (2006), Tekhnolohii elektronnoho vriaduvannia [Technologies of electronic government], Tsentr spryiannia instytutsijnomu rozvytku derzhavnoi sluzhby, Kyiv, Ukraine.

5. Klymenko, I.V. Panchuk, A.M. Ralduhin, Ye.O. and Lytvynova, H.S. (2004), Modeliuvannia, informatsijni systemy i tekhnolohii v derzhavnomu upravlinni [Modeling, information systems and technologies in public administration], Tsentr navchal'noi literatury, Kyiv, Ukraine.

6. Mokhova, Yu. and Orlova, N. (2021), "The role of digital competencies in the formation of digital society", Naukovi perspektyvy, vol. 5 (11), pp. 154-162.

7. Orlova, N. and Mokhova, Yu. (2021), "European guidelines for digital transformations in e-government", Naukovi perspektyvy, vol. 7 (13), pp. 97-106.

8. Spasibov, D. (2018), "E-government in the system of modern concepts of public administration", Teoriia ta praktyka derzhavnoho upravlinnia, [Online], vol. 2 (61), available at: http://www.kbuapa.kharkov.ua/e-book/ tpdu/2018-2/index.html (Accessed 20 December 2021).

9. Furashev, V. (2005), Elektronne informatsijne suspil'stvo Ukrainy: pohliad u s'ohodennia i majbutnie [Electronic information society of Ukraine: a look at the present and the future], Inzhynirynh, Kyiv, Ukraine.

10. National Academy of Sciences of Ukraine (2020), "Assessment of electronic readiness of Ukraine", available at: https://www.nas.gov.ua/siaz/Ways_of_development_of_Ukrainian_science/article/14026.1.007.pdf (Accessed 20 December 2021).

11. Pension Fund of Ukraine (2021), "Report for 2020", available at: https://docs.google.com/viewer?url=https://www.pfu.gov.ua/content/uploads/2021/03/ Zvit_pro_robotu_ta_vykonannya_byudzhetu_PFU_2020.pdf (Accessed 20 December 2021).

12. Action. State Tax Service of Ukraine (2021), "The State Tax Service provided more than 15 million services on the portal of the year", available at: https://cabinet.tax.gov.ua/news/C9F9362A183F0014E0530A5028077926 (Accessed 20 December 2021).

13. National Health Service of Ukraine (2021), "Report of the National Health Service for 2020", available at: file:/ //D: /\%D0\%B4\%D0\%B8\%D1\%81\%D0\%B5\%D1\%80\%D1\%82\%D0\%B0\%D1\%86\%D0\%B8\%D1\%$8 \mathrm{~F} / \%$ D $0 \%$ B $4 \%$ D $0 \%$ BE \% D $0 \%$ B A \% D $1 \%-$ $82 \%$ D $0 \%$ BE \% D $1 \% 80 \%$ D $1 \% 81 \%$ D $\% \%$ BA \% D0\%B0\%D1\%8F/nhsu-annual-report-2020-ua-web.pdf (Accessed 20 December 2021).

14. National Agency of Ukraine for Civil Service (2020), "Analitychnyj zvit pro indyvidual'ni potreby u profesijnomu navchanni derzhavnykh sluzhbovtsiv na 2021 rik" [Analytical report on individual training needs of civil servants for 2021], National Agency of Ukraine for Civil Service, Kyiv, Ukraine.

15. Portal of the Ministry of Internal Affairs of Ukraine (2021), "Half a century of informatization: the development of the information service of the Ministry of Internal Affairs and its largest projects digitization", available at: https:/ /mvs.gov.ua/uk/press-center/news/pivstolittyainformatizaciyi-rozvitok-informaciinoyi-sluzbi-mvs-tayiyi-naibilsi-projekti-cifrovizaciyi (Accessed 20 December 2021).

16. Portal of the Ministry of Internal Affairs of Ukraine (2021), "Cyberpolice", available at: https://mvs.gov.ua/ uk/press-center/infographics/kiberpoliciya-2018 (Accessed 20 December 2021).

Стаття надійшла до редакиї 23.12.2021 p. 